\title{
EKSISTENSI PENDIDIKAN ISLAM DI MESIR MASA DAULAH FATIMIYAH Lahirnya Al-Azhar, Tokoh-tokoh Pendidikan pada Masa Daulah Fatimiyah dan Pengaruhnya terhadap Dunia Islam
}

\author{
Asriati Amaliyah \\ STAI DDI Parepare dan Pondok Pesantren DDI Lil-Banat \\ Jl. Abu Bakar Lambogo No. 53 Soreang Parepare \\ Email: asriati_amaliyah130980@yahoo.co.id
}

\begin{abstract}
Abstrak:
Pada dasarnya pendidikan Islam merupakan sarana yang terpenting untuk membawa manusia mencapai tujuan hidupnya. Melalui pendidikan, kehidupan individu dapat menjadi suatu pribadi yang mampu berdiri sendiri dan berinteraksi dalam kehidupan bersama dengan orang lain secara konstruktif. Pendidikan mampu membentuk dan membangun sebuah peradaban yang agung pada zamannya. Pada masa Daulah Fatimiyah, pendidikan Islam berkembang dengan pesat dan maju. Al-Azhar pada masa Dinasti Fatimiyah merupakan lembaga pendidikan Islam yang memberikan kontribusi nyata pada dunia pendidikan Islam pada masa itu. Pada masa itu al-Azhar mampu melahirkan tokoh-tokoh pendidikan Islam yang menjadi pemegang tampuk kepemimpinan di al-Azhar dan memberikan konstruksi pemikiran yang sampai sekarang masih dapat dijadikan referensi.
\end{abstract}

\begin{abstract}
:
Basically Islamic education is the most important means to bring people achieving their life goals. Education brings people into a personal life which is able to stand alone and interact in a common life with others constructively. Education is able to establish and build a great civilization in his day. During the Fatimid Dynasty, Islamic education was growing rapidly and advanced. Al-Azhar in Fatimid Dynasty was an Islamic educational institutions that make a real contribution to the world of Islamic education. At that time, it emerged educational leaders who were the holders of leadership in al-Azhar and provide a way of thinking that can still be used as a reference now.
\end{abstract}

Kata Kunci:

Daulah Fatimiyah, Pendidikan Islam Al-Azhar

ISLAM memiliki sifat universal dan kosmopolit yang dapat merambah ke ranah kehidupan apa pun, termasuk dalam ranah pendidikan. Ketika Islam dijadikan sebagai paradigma ilmu pendidikan, paling tidak berpijak pada tiga alasan. Pertama, ilmu pendidikan sebagai ilmu humaniora tergolong ilmu normatif, karena ia terkait oleh norma-norma tertentu. Pada taraf ini, nilai-nilai Islam sangat berkompoten untuk dijadikan norma dalam ilmu pendidikan. Kedua, dalam menganalisis masalah pendidikan, para ahli selama ini cenderung mengambil teori dan falsafah pendidikan Barat. Falsafah pendidikan Barat lebih bercorak sekuler yang memisahkan berbagai dimensi kehidupan, sedangkan masyarakat Indonesia lebih bersifat religius. Atas dasar ini, nilai-nilai ideal Islam sangat memungkinkan untuk dijadikan acuan dalam mengkaji fenomena kependidikan. Ketiga, dengan menjadikan Islam sebagai paradigma, keber- 
adaan ilmu pendidikan memiliki ruh yang dapat menggerakkan kehidupan spiritual dan kehidupan yang hakiki. ${ }^{1}$

Konsep pendidikan Islam pada hakikatnya berupaya menjadikan manusia mencapai keseimbangan kepribadiannya secara menyeluruh, dan dilakukan melalui tahapan tertentu. Rumusan pendidikan Islam harus dikaitkan dengan pemikiran filosofis pendidikan Islam. Pendidikan Islam dibangun di atas konstruksi wahyu Alquran dan Sunnah sebagai sumber utamanya. Pendidikan Islam juga memiliki asas dan landasan hukum yang tetap terbangun dari kedua sumber utama tersebut.

Pendidikan Islam dari masa ke masa, mulai dari zaman Rasulullah saw., Khulafa al-Rasyidin sampai terbentuknya Daulah Umayyah dan Daulah Abbasiyah hingga sekarang telah memberikan konstribusi nyata bagi perkembangan dunia, khususnya umat Islam itu sendiri. Salah satunya adalah Daulah Fatimiyah di Mesir.

Afrika Utara sampai tahun $850 \mathrm{M}$ dikuasai oleh Bani Aghlab, meliputi wilayah Ifriqiyah (Tunisia) dan sebagian pulau Sisilia, merupakan negara bagian Daulah Abbasiyah. Wilayah sebelah baratnya berkuasa Bani Rustamiyah di Aljazair dan Bani Idris di Maroko, sedangkan Spanyol berada di bawah kekuasaan Bani Umayyah II. Semua Dinasti ini berkuasa sampai tahun 909. Namun sesudah tahun 909 muncul sebuah dinamika baru, terbentuknya sebuah negara Fathimiyah di Tunisia. ${ }^{2}$

Dinasti Fathimiyah adalah Dinasti Syi'ah yang berkuasa dari 909 M (296 H) sampai dengan $1171 \mathrm{M}(569 \mathrm{H})$ atas dasar legitimasi klaim keturunan Nabi lewat Fatimah $^{3}$ dan Hadzrat Ali dari Ismail anak Jafar Sidik, keturunan keenam dari Ali. ${ }^{4}$ Dinasti ini didirikan sebagai tandingan bagi penguasa dunia muslim saat itu yang terpusat di Baghdad, yaitu Bani Abbasiyah. ${ }^{5}$ Wilayah kekuasaan Dinasti Fatimiyah meliputi Afrika Utara, Mesir, dan Suriah. Berdirinya Dinasti Fatimiyah dilatarbelakangi oleh melemahnya Dinasti Abbasiyah. Ubaidillah al-Mahdi mendirikan Dinasti Fatimiyah yang lepas dari kekuasaan Abbasiyah. ${ }^{6}$

Masa kegemilangan Dinasti Fatimiyah ditandai dengan berpindahnya pusat pemerintahan ke Kairo. Setelah Kairo berdiri dan dilengkapi dengan berbagai sarana termasuk masjid Al-Azhar ${ }^{7}$ yang kemudian dijadikan pusat Perguruan Tinggi Islam oleh khalifah Fathimiyah al-Aziz (975 M- 996 M). Jauhar juga mendirikan Dar al-Hikmah di tahun 1005 M. Kemudian Dinasti Fatimiyah yang ditopang dengan wilayah pengaruhnya yang luas mampu membangkitkan berbagai kegiatan ilmiah, perdagangan, dan keagamaan. ${ }^{8}$

Semenjak abad ke- 10 pada masa Dinasti Fatimiyah yang membangun institusi pendidikan yang sekarang dikenal dengan nama Universitas al-Azhar, Mesir menjadi pusat peradaban dan pengembangan ilmu-ilmu keislaman. Ribuan tahun Sebelum Masehi, negara para Pharao ini telah menjadi pusat peradabana dunia, di samping peradaban lain seperti Mesopotamia dan Bizantium. Tiap peradaban yang maju, pasti disokong oleh luhurnya ilmu pengetahuan dari manusia yang memiliki peradaban tersebut. Artinya hanya bangsa dengan ilmu pengetahuan yang tinggi akan mampu sampai pada peradaban yang mulia. ${ }^{9}$ 


\section{PEMBAHASAN}

\section{Pendidikan Islam di Mesir pada Masa Dinasti Fatimiyah}

Pada masa-masa awal, proses pendidikan Islam berlangsung di tempat-tempat yang merupakan pusat ibadah (masjid). Namun karena banyaknya umat Islam yang berminat untuk belajar sedangkan kapasitas masjid tidak lagi mencukupi, juga mengganggu kegiatan orang-orang yang beribadah, institusi pendidikan mulai mengadakan pembenahan-pembenahan. ${ }^{10}$

Ibnu Killis adalah salah seorang tokoh dan pelopor perkembangan pendidikan pada kekhalifahan Fatimiyah di Mesir. Ia mendirikan sebuah universitas dan menghabiskan ribuan dinar per bulan untuk membiayainya. Di bawah kekuasaannya, tersebutlah seorang dokter yang sangat terkenal bernama Muhammad al-Tamim, yang lahir di Yerussalem dan pindah ke Mesir sekitar tahun 970 M. ${ }^{11}$ Salah satu fondasi terpenting yang dibangun pada masa Fatimiyah adalah pembangunan Dar al-Hikmah (rumah kebijaksanaan) atau Dar al-'Ilm (rumah ilmu) yang didirikan oleh al-Hakim pada tahun 1005 sebagai pusat pembelajaran dan penyebaran ajaran Syi'ah ekstrim. ${ }^{12}$

Perpustakaan Dar al-Hikmah di Kairo ini didirikan oleh al-Hakim Biamrillah. Perpustakaan ini dibuka pada tanggal 10 Jumadil Akhir tahun $395 \mathrm{H}$, setelah dilengkapi perabotan dan hiasan. Pada semua pintu dan lorongnya dipasangi tirai. Di perpustakaan tersebut ditempatkan para penanggung jawab, karyawan, dan petugas. Dihimpun pula buku-buku yang belum pernah dihimpun oleh seorang raja pun. Perpustakaan itu mempunyai 40 lemari. Salah satu lemari memuat 18.000 buku tentang ilmu-ilmu kuno. Semua orang boleh masuk ke situ. Di antara mereka ada yang datang untuk membaca buku, menyalin, atau belajar. Di tempat tersebut terdapat segala sesuatu yang diperlukan oleh pengunjung (tinta, pena, kertas, dan tempat tinta). ${ }^{13}$

Untuk mengembangkan institusi ini, al-Hakim mengeluarkan dana sebesar 257 dinar di antaranya digunakan untuk menyalin berbagai naskah, memperbaiki buku, dan pemeliharaan umum lainnya. Gedung ini dibangun berdekatan dengan istana kerajaan yang di dalamnya terdapat sebuah perpustakaan dan ruang-ruang pertemuan. Kurikulumnya meliputi kajian tentang ilmu-ilmu keislaman, astronomi, dan kedokteran. ${ }^{14}$

Pada masa al-Mustanshir, kegagalan atau kemunduran kerajaan yang mengakibatkan berkurangnya harta kekayaan, pada gilirannya menyebabkan kemunduran lebih besar dengan banyaknya buku-buku yang hilang dari perpustakaan kerajaan. Perpustakaan itu sendiri mulai didirikan pada masa al-'Aziz, ketika itu memiliki kurang lebih 200.000 buku dan 2.400 eksemplar al-Quran yang dihiasi ornamen-ornamen indah. Salah satu koleksi langka perpustakaan ini adalah naskah-naskah hasil karya Ibn Muqlah dan ahli-ahli kaligrafi lainnya. Di perpustakaan ini pula al-'Aziz menyimpan salinan tulisan tangan untuk buku sejarah karya al-Thabari. Pengganti alMustanshir membangun kembali sebuah perpustakaan. Ketika satu abad kemudian Shalah-al-Din menguasai istana kerajaan, perpustakaan istana itu masih menyimpan sekitar 100.000 jilid buku, sebagian dari buku-buku itu disertai harta rampasan lainnya dibagikan kepada bawahannya. ${ }^{15}$ 
Bangunan tua yang masih bertahan hingga kini adalah masjid al-Azhar yang didirikan oleh Jauhar as-Siqili. Meskipun sudah pernah dipugar, keaslian bagian tengahnya yang merupakan pusat bangunan ini tetap dipertahankan. Bagian ini dibangun dari batu bata, mengikuti model masjid Ibnu Thulun, yang memiliki sudut mihrab, dan secara umum berbeda jauh dengan gaya Persia. Menara masjid ini berbentuk bundar konvensional. 16

Seni penjilidan buku di dunia Islam yang paling pertama dikenal datang dari Mesir sekitar abad ke-8 atau 9.17 Teknik dan dekorasi yang mereka miliki bersanding indah dengan daya tarik seni penjilidan koptik yang lebih dulu muncul, dan yang nyata-yata menjadi patokan keahlian menjilid. Setelah mazhab Mesir dalam seni penjilidan berkembang, teknik menghiasi sampul buku dengan alat dan stempel menjadi teknik yang banyak dipakai oleh para perajin yang menggunakan kulit.

\section{Sejarah Lahirnya al-Azhar}

Dari sekian universitas di dunia Islam, dua yang tertua dan hingga kini masih ada, adalah Universitas al-Karaouiyinne di Fez, Maroko dan al-Azhar di Kairo. ${ }^{18}$ AlAzhar merupakan lembaga pendidikan bertaraf internasional yang berpusat di Kairo, Mesir. Kemampuannya menghadapi perubahan dan menjawab tantangan telah terbukti. Al-Azhar mula-mula didirikan sebagai masjid oleh panglima Fatimiyah, ${ }^{19}$ Jenderal Jauhar as-Siqili pada tanggal 24 Jumadil Ula $359 \mathrm{H}$ dan selesai pembangunannya pada bulan Ramadhan $361 \mathrm{H},{ }^{20}$ setelah Mesir pada tahun 969 (354 H) secara penuh dikuasainya. ${ }^{21}$ Menurut sumber yang dikutip Van Houve dalam Ensiklopedi Islam menyebutkan bahwa al-Azhar berdiri pada tahun 359 H/970 M. Mahmud Yunus dalam bukunya Sejarah Pendidikan Islam mengutip berdirinya al-Azhar pada Tahun 358 H. Adapun waktu pembangunan al- Azhar hingga selesai tidak ada perbedaan yaitu setahun. ${ }^{22}$

Nama masjid al-Azhar merupakan nama yang dinisbatkan kepada putri Nabi Muhammad Saw. Fatimah al-Zahrah. Sebelumnya nama masjid tersebut adalah alQahirah yang berarti sama dengan nama kota, yaitu Cairo, dan dikaitkan dengan kata-kata al-Qohirah al-Zahirah yang berarti kota yang cemerlang. ${ }^{23}$ Baru setelah 26 bulan berlalu, al-Azhar dibuka untuk umum, tepatnya pada bulan Ramadhan $361 \mathrm{H}$ dengan diawali kuliah agama perdana oleh al-Qodi Abu Hasan al-Qoirowani pada masa pemerintahan Malik al-Nasir. ${ }^{24}$

Masjid al-Azhar adalah pusat ilmu pengetahuan, tempat diskusi bahasa dan juga mendengarkan kisah dari orang yang ahli bercerita. Masjid ini sebenarnya diperuntukkan bagi Dinasti Fatimiyah yang sedang bersaing dengan kekhalifahan di Baghdad. Usaha yang dilakukannya ialah dengan mengajarkan mazhab Syi'ah kepada kader-kader mubaligh yang bertugas meyakinkan masyarakat akan kebenaran mazhab yang dianutnya. ${ }^{25}$ Ia merupakan lembaga Fatimiyah sebagai pusat latihan kader penyebar ideologi Syi' ah yang mengancam otoritas Abbasiyah Sunni. Maka dinasti Saljuk Abbasiyah mendirikan lembaga-lembaga pendidikan teologi ortodoks sebagai upaya mengimbangi upaya al-Azhar. Sebagai sebuah gerakan politik dan keagamaan, Khalifah Fatimiyah menaruh perhatian khusus atas penyebaran doktrin-doktrin ter- 
tentu (dakwah Fathimiyah) melalui para "kader" (dai). Program yang dilontarkan kaum Fathimiyyin meliputi dua tahap: tahap pertama, pelaksanaan pengajaran serta pembentukan undang-undang; tahap kedua, dakwah secara rahasia. ${ }^{26}$

Untuk memenuhi kebutuhan terhadap tenaga para dai inilah al-Azhar kemudian ditingkatkan peranannya bukan hanya sebagai masjid melainkan juga sebagai lembaga pendidikan yang terorganisir di bawah pengawasan khalifah. ${ }^{27} \mathrm{Al}$-Azhar pada masa Dinasti Fathimiyah merupakan lembaga pendidikan yang menjadi corong dan alat untuk propaganda kekuasaan kekhalifahan, sekaligus sebagai alat penyebaran doktrin ajaran syi'ah.

Al-Azhar tampak berbeda dengan madrasah sebelumnya. Pada lembaga ini sudah dilengkapi dengan asrama untuk guru-guru dan para mahasiswa, juga aula besar (iwan) yang dipergunakan untuk kuliah umum. Iwan merupakan bagian yang sangat penting bagi al-Azhar. Pelaksanaan proses belajar mengajar di al-Azhar mengacu kepada aturan-aturan yang ditetapkan oleh pengelola madrasah. Peranan al-Azhar sebagai madrasah yang menyelenggarakan pendidikan tingkat tinggi, menurut Philip K. Hitti merupakan lembaga pendidikan tingkat tinggi (institution of higher education) atau college (akademi menurut perbandingan pendidikan sekarang). ${ }^{28}$

Al-Azhar pada masa Dinasti Fathimiyah merupakan lembaga pendidikan yang menjadi corong dan alat untuk propaganda kekuasaan kekhalifahan, sekaligus sebagai alat penyebaran doktrin ajaran syi'ah. Pada masa itu, sistem pengajaran terbagi menjadi empat kelas, yaitu: Pertama, kelas umum diperuntukkan bagi orang yang datang ke al-Azhar untuk mempelajari al-Quran dan penafsirannya; Kedua, kelas para mahasiswa Universitas al-Azhar kuliah dengan para dosen yang ditandai dengan mengajukan pertanyaan dan mengkaji jawabannya; Ketiga, Kelas Darul Hikam, kuliah formal ini diberikan oleh para mubaligh seminggu sekali pada hari Senin yang dibuka untuk umum dan pada hari Kamis dibuka khusus untuk mahasiswa pilihan. Keempat, kelas nonformal, yaitu kelas untuk pelajar wanita. ${ }^{29}$

Pada mulanya pengajaran di Universitas al-Azhar sama dengan institusi pendidikan yang lain, yaitu sistem halaqah (melingkar). Seorang pelajar bebas memilih guru dan pindah sesuai dengan kemauannya. Umumnya guru atau syaikh yang mengajar itu duduk bersama para pelajar, tetapi guru kadang-kadang duduk di kursi ketika menerangkan kitab yang diajarkannya. Di samping itu, metode diskusi sangat dikembangkan sebagai metode dalam proses pembelajaran antarpelajar. Seorang guru hanya berperan sebagai fasilitator dan memberikan penajaman dari materi yang didiskusikan. ${ }^{30}$

Pada masa khalifah al-Aziz Billah, 387 H/988 M dengan usaha wazirnya, Yakub Ibn Kills, al-Azhar dijadikan sebagai Universitas Islam yang mengajarkan ilmu-ilmu agama, ilmu akal (logika) dan ilmu umum lainnya. Untuk menunjang kegiatan pendidikan dan pengajaran, al-Azhar dilengkapi dengan asrama untuk para fuqaha (dosen, tenaga pendidik) serta semua urusan dan kebutuhannya ditanggung oleh khalifah. ${ }^{31}$ 
Adapun tujuan Universitas al-Azhar adalah: (1) mengemukakan kebenaran dan pengaruh turas Islam terhadap kemajuan umat manusia dan jaminannya terhadap kebahagiaannya di dunia dan akhirat; (2) memberikan perhatian penuh terhadap kebangkitan turas ilmu, pemikiran, dan keruhanian bangsa Arab Islam; (3) menyuplai dunia Islam dengan ulama-ulama aktif yang beriman, percaya terhadap diri sendiri, mempunyai keteguhan mental dan ilmu yang mendalam tentang akidah, syariah, dan bahasa al-Quran; (4) mencetak ilmuwan agama yang aktif dalam semua bentuk kegiatan, karya, kepemimpinan dan menjadi contoh yang baik, serta mencetak ilmuwan dari berbagai ilmu pengetahuan yang sanggup aktif dalam dakwah Islam yang dipimpin dengan hikmat kebijaksanaan dan pelajaran yang baik di luar dan di dalam Republik Arab Mesir; (5) meningkatkan hubungan kebudayaan dan ilmiah dengan universitas dan lembaga ilmiah Islam di luar negeri. ${ }^{32}$

Al-Azhar sebagai lembaga pendidikan tinggi saat itu, telah banyak melahirkan ulama yang tidak diragukan lagi dari aspek keilmuannya, dan telah banyak menyumbangkan khasanah ilmu pengetahuan terutama ke-Islaman, baik dari Mesir maupun ulama yang berasal dari daerah lainnya. Di antara mereka ialah Izauddin bin Abdissalam, Imam Subki, Jalaluddin as-Suyuti, al-Hafiz Ibnu Hajar al-Asqalani, dan lain-lain. ${ }^{33}$

Al-Azhar mempunyai peranan penting dalam perkembangan pendidikan di Eropa. Pemakaian seragam sekolah, pengembangan tradisi pembantahan, penjurusan dua buah fakultas. Fakultas graduate dan undergraduate berasal dari tradisi al-Azhar dan menunjukkan pengaruh kuat lembaga al-Azhar. ${ }^{34}$

Perubahan orientasi al-Azhar terjadi menyusul ambruknya kekhalifahan Fatimiyah di Kairo. Setelah hampir 200 tahun digunakan Bani Fatimiyah sebagai basis pendidikan dan penyebaran doktrin-doktrin Syi' ah, al-Azhar diambil alih Salahuddin al-Ayyubi untuk dijadikan madrasah-masjid yang berorientasi Sunni. Berlainan dengan Bani Fatimiyah yang menekankan pengajaran filosofis dan teologis, Dinasti Ayyubi, sebagaimana penguasa dan pemuka Sunni yang lain, lebih mementingkan pengajaran fikih dalam madrasah yang mereka kelola, termasuk al-Azhar. Pengambilalihan ini, sebenarnya telah mereduksi posisi al-Azhar yang berorientasi supralokal menjadi lembaga yang berwawasan sempit dikarenakan lingkup politik Dinasti Ayyubiyah yang bercorak lokal. Hanya karena peranan Kairo yang strategis dalam perjalanan sejarah Islam akhirnya bisa diperoleh kembali dan dipertahankan, khususnya pada zaman modern. ${ }^{35}$

Setelah al-Ayyub menaklukkan Mesir tahun 1171 M selama hampir satu abad dari tahun 1171-1267 M, al-Azhar dikosongkan. Pada abad kekosongan itu salat Jumat di masjid al-Azhar pun dilarang dan pindah ke masjid al-Hakim, karena mereka berpemahaman tidak boleh ada dua khutbah di dalam satu kota. Semenjak itulah Dinasti Fatimiyah berakhir sehingga al-Azhar berubah menjadi universitas Sunni. Ia telah mencapai prestasi yang gemilang dan reputasi sebagai otoritas bidang keagamaan sampai sekarang tetap berlangsung. ${ }^{36}$ 
Tidak diketahui respons negatif dari masyarakat sekitar al-Azhar, tapi penulis berpendapat sekecil apapun respons negatif itu pasti ada. Adapun respon positif telah diketahui dengan semakin banyaknya umat Islam yang menuntut ilmu di al-Azhar, bukan saja dari Mesir, melainkan dari seluruh dunia.

\section{Tokoh-tokoh Pendidikan pada Masa Daulah Fatimiyah dan Pengaruhnya terhadap Dunia Islam}

Pada masa Daulah Fatimiyah, seiring dengan lahir dan berkembangnya Universitas al-Azhar, muncul pula tokoh-tokoh pendidikan yang memegang peranan penting pada masa itu, di antaranya.

\section{Syaikh Imam Ibrahim al-Barmawi}

Syaikh Ibrahim bin Muhammad bin Syihabuddin bin Khalid al-Barmawi ketika belajar di al-Azhar mendalami bidang ilmu syariah dan bahasa. Kemudian setelah lulus dari al-Azhar, ia langsung menjadi tenaga pengajar di almamaternya. Kariernya berkembang cukup pesat sehingga beliau pernah menjabat sebagai syaikh al-Azhar pada tahun $1694 .{ }^{37}$

\section{Syaikh Muhammad Abbasi al-Mahdi al-Hanafi}

Syaikh Muhammad Abbasi al-Mahdi al-Hanafi adalah rektor Al-Azhar ke-21. Dia bermazhab Hanafi pertama yang memegang jabatan rektor. Di antara pembaruan yang dilakukannya adalah pada bulan Februari 1872 M memasukkan sistem ujian untuk mendapatkan ijazah al-Azhar. Calon alim harus berhadapan dengan suatu tim beranggotakan 6 orang syaikh yang ditunjuk oleh syaikh al-Azhar, untuk menguji bidang studi usul, fikih, tauhid, hadis, tafsir, dan ilmu-ilmu bahasa seperti nahu, saraf (ilmu tentang pembentukan kata), ma'ani, bayan, badi', dan mantik. Kandidat yang berhasil lulus berhak mendapatkan asy-syahadah al-'alamiyah (ijazah kesarjanaan). Pada bulan Maret $1885 \mathrm{M}$, keluar undang-undang mengenai pengaturan tenaga pengajar setelah ia dapat menyelesaikan buku-buku induk dalam 12 bidang studi. Kandidat yang lulus dalam ujian ini mendapat al-darajah al-'ulya (tingkat pertama), al-darajah alsaniyah (tingkat dua), al-darajah al-tsalisah (tingkat ketiga). ${ }^{38}$ Lulusan nilai pertama dapat bekerja sebagai pengajar untuk buku-buku tingkatan tinggi, nilai kedua untuk buku-buku tingkatan menengah, dan nilai ketiga untuk buku-buku tingkatan dasar.

Syaikh Muhammad Abduh

Muhammad Abduh ${ }^{39}$ termasuk pembaharu agama dan sosial di Mesir pada zaman modern. Dialah penganjur yang sukses dalam membuka pintu ijtihad untuk menyesuaikan Islam dengan tuntutan zaman modern. ${ }^{40}$ Pada tahun $1877 \mathrm{M}$ ia telah menyelesaikan studinya di al-Azhar dengan meraih gelar alim. Setelah itu, ia mulai mengajar, mulanya di Al-Azhar sendiri, kemudian di Daral-Ulum. ${ }^{41}$ Pada mulanya tokoh pembaharu ini mendapat tantangan dari ulama konservatif, tetapi setelah al-Azhar dipegang oleh Syaikh al-Nawawi (teman akrabnya), ia mendapat kesempatan mengadakan sedikit pembaruan. ${ }^{42}$ Menurut Muhammad Abduh, pendidikan memer- 
lukan pembaruan. Pelajar-pelajar madrasah harus mempelajari ilmu pengetahuan modern, sehingga mereka bisa membantu muslim memasuki dunia baru dalam konteks Islam yang akan sangat berarti bagi mereka semua. ${ }^{43}$ Dia yakin bahwa apabila alAzhar ingin diperbaiki, pembenahan administrasi dan pendidikan di dalamnya pun harus dibenahi, kurikulumnya diperluas, mencakup sebagian ilmu-ilmu modern, sehingga al-Azhar dapat berdiri sejajar dengan universitas-universitas lain di Eropa serta menjadi mercusuar dan pelita bagi kaum muslim pada zaman modern. Menurutnya, ada dua pilihan untuk al-Azhar: maju atau hancur sama sekali. Ketika Abbas Hilmi naik ke pentas kekuasaan, dia mengeluarkan keputusan untuk membentuk sebuah panitia yang mengatur al-Azhar. Dalam kepanitiaan itu, Muhammad Abduh mewakili pemerintah dan menjadi pemrakarsanya. Panitia itu berhasil menaikkan gaji para guru-guru yang miskin, memperhatikan tempat tinggal dan kesehatan orangorang yang tinggal di sekitarnya, serta memperbaiki kondisi perpustakaannya yang sangat menyedihkan. Hal yang paling penting adalah menambahkan mata pelajaran, yaitu berhitung, al-jabar, sejarah Islam, bahasa dan sastra, dan prinsip-prinsip geometri dan geografi. ${ }^{4}$

Secara berangsur-angsur, ia mulai melakukan pengaturan libur yang lebih pendek dan masa belajar yang lebih diusahakan untuk dihilangkan. Sementara itu, ia juga memasukkan kurikulum modern, seperti fisika, ilmu pasti, filsafat, sosiologi, dan sejarah ke al-Azhar. Di samping masjid, didirikan Dewan Administrasi al-Azhar (idarah al-Azhar) dan diangkat beberapa orang sekretaris untuk membantu kelancaran tugas Syaikh al-Azhar. Bersamaan dengan ini, juga dibangun oleh Rauq al-Azhar yang dapat memenuhi kebutuhan pemondokan bagi guru-guru dan mahasiswa-mahasiswanya. 45

Dalam bidang metode pengajaran, ia pun membawa cara baru dalam dunia pendidikan saat itu. Ia mengkritik dengan tajam penerapan metode hapalan tanpa pengertian yang umumnya dipraktikkan di sekolah-sekolah saat itu, terutama sekolah agama. Ia tidak menjelaskan dalam tulisan-tulisannya metode apa yang sebaiknya diterapkan, tetapi dari apa yang dipraktikkannya ketika ia mengajar di al-Azhar tampaknya bahwa ia menerapkan metode diskusi untuk memberikan pengertian yang mendalam pada muridnya.

\section{Syaikh Mahmud Syaltut}

Syaikh Mahmud Syaltut, adalah rektor al-Azhar ke-4146 yang membentuk organisasi untuk mengatur "pemeliharaan al-Qur'an" dan membentuk fakultas-fakultas baru antara lain: Fakultas Kedokteran, Fakultas Pertanian, dan Fakultas Teknik. ${ }^{47}$

\section{Syaikh Imam Muhammad Al-Maraghi}

Syaikh Imam Muhammad al-Maraghi belajar di al-Azhar dari seorang ulama yang terkemuka, yaitu Syaikh Muhammad Abduh. Setelah lulus dari al-Azhar beliau langsung mengabdikan diri pada almamaternya. Al-Maraghi menjabat sebagai syaikh al-Azhar selama dua kali, yaitu pada tahun $1928 \mathrm{M}$ dan pada tahun $1935 \mathrm{M}$ sampai tahun 1945 M. Dia diangkat kembali sebagai syaikh al-Azhar untuk kedua kalinya. Ke- 
tika al-Maraghi belajar di al-Azhar, sistem dan metode pembelajaran yang berlaku masih bersifat tradisional, yaitu dengan sistem halaqah, kemudian begitu beliau menjabat sebagai syaikh al-Azhar langsung mengadakan pembaruan dan restrukturisasi berupa peraturan undang-undang tentang sistem pembelajaran di al-Azhar.

\section{SIMPULAN}

Dari pemaparan tersebut, maka dapat disimpulkan bahwa:

1. Pada masa-masa awal, proses pendidikan Islam berlangsung di tempat-tempat yang merupakan pusat ibadah (masjid). Namun karena banyaknya umat Islam yang berminat untuk belajar sedangkan kapasitas masjid tidak lagi mencukupi, juga mengganggu kegiatan orang-orang yang beribadah, institusi pendidikan mulai mengadakan pembenahan-pembenahan.

2. Pada awalnya al-Azhar bukan sebagai perguruan tinggi, tetapi al-Azhar merupakan sebuah masjid yang oleh Khalifah Fatimiyah dijadikan sebagai pusat untuk menyebarkan dakwah mereka.

3. Adapun tokoh-tokoh pada masa Dinasti Fatimiyah di antaranya: Syaikh Imam Ibrahim al-Barmawi (syaikh al-Azhar pada tahun 1694), Syaikh Muhammad Abbasi al-Mahdi al-Hanafi (rektor al-Azhar ke-21), Syaikh Muhammad Abduh (1849-1905), dan Syaikh Mahmud Syaltur (rektor al-Azhar ke-41), Syaikh Imam Muhammad Al-Maraghi (syaikh al-Azhar selama dua kali, yaitu pada tahun $1928 \mathrm{M}$ dan pada tahun 1935 sampai tahun $1945 \mathrm{M}$ ).

\section{CATATAN AKHIR}

1. Makna Islam sebagai paradigma ilmu pendidikan adalah suatu konstruksi pengetahuan yang memungkinkan memahami realitas ilmu pendidikan. Konstruksi pengetahuan itu dibangun oleh nilai-nilai Islam dengan tujuan agar kita memiliki hikmah (wisdom). Lihat: Abdul Mujib dan Jusuf Mudzakkir, Ilmu Pendidikan Islam, Cet. II; Jakarta: Kencana, 2008, h. $1-2$.

2. Musyrifah Sunanto, Sejarah Islam Klasik Perkembangan Ilmu Pengetahuan Islam, Cet. III; Jakarta: Kencana, 2007, h. 141.

3. Tim Penulis IAIN Syarif Hidayatullah, Ensiklopedi Islam Indonesia, Cet. 2; Jakarta: Djambatan, 2002, h. 293.

4. Ajid Thohir, Perkembangan Peradaban di Kawasan Dunia Islam Melacak Akar-akar Sejarah, Sosial, Politik, dan Budaya Umat Islam, Cet. I; Jakarta: PT. Raja Grafindo Persada, 2009, h. 112.

5. Philip K. Hitti, History of The Arabs, Terj. R. Cecep Lukman Yasin dan Dedi Slamet Riyadi dengan judul Sejarah Arab, Cet. I; Jakarta: PT. Serambi Ilmu Semesta, 2008, h. 787.

6. Samsul Munir Amin, Sejarah Peradaban Islam, Cet. I; Jakarta: Amzah, 2009, h. 254.

7. Yang bercahaya atau yang adil, (al-Zahra, julukan untuk Fatimah), lihat: Philip K Hitti, op. cit., h. 790.

8. Tim Penulis IAIN Syarif Hidayatullah, loc. cit..

9. www.sunanampel.ac.id/index. Php? Limitstart=118 dan lang=in, diakses tanggal 3 Desember 2012.

10. Abuddin Nata, Sejarah Pendidikan Islam Pada Periode klasik dan Pertengahan, Cet. I; Jakarta: PT. Raja Grafindo Persada, 2004, h. 87. 
11. Philip K Hitti, op. cit., h. 800.

12. Ibid.

13. Mustafa Husni al-siba'i, Min Rawaa'i Hadaraatina, di terj. Abdullah Zakiy al-Kaaf dg jdul, Khazanah Peradaban Islam, Cet. I;Bandung: Pustaka Setia, 2002, h. 207.

14. Philip K.Hitti, op. cit., h. 801.

15. Ibid., h.803

16. Batu-batu yang digunakan untuk membangun masjid al-Hakim itu saat ini telah runtuh. Karena menaranya tidak berbentuk segi empat, bisa dikatakan bahwa tukang-tukangnya berasal dari Irak Barat, bukan dari Suriah. Lihat: Ibid.

17. Ibid., h. 806.

18. Famhar, Universitas Kelas Dunia, Multiply.com/journal/item/189, diakses tanggal 6 Desember 2010.

19. Tim Penulis IAIN Syarif Hidayatullah, op. cit., h. 134.

20. Abuddin Nata, op. cit., h. 88.

21. Tim Penulis IAIN Syarif Hidayatullah, op. cit., h. 134.

22. Abuddin Nata, op. cit.,h. 188.

23. Hanun Asrohah, Sejarah Pendidikan Islam, Cet. I; Jakarta: Logos, 1999, h. 60, Lihat juga: Abuddin Nata, op. cit., h. 189.

24. Muhammad Atiyah al-Abrasyi, al-Tarbiyah al-Islamiyah diterj. Bustami A. Gani dan Johar Bahri dengan judul Dasar-dasar Pokok Pendidikan Islam, Cet. VIII; Jakarta: Bulan Bintang, 1993, h. 61, Lihat juga: Abuddin Nata, op. cit., h. 90.

25. Ibid.

26. Abuddin Nata, op. cit., h. 188-189.

27. Tim Penulis IAIN Syarif Hidayatullah, loc. cit.

28. Abuddin Nata, op. cit., h. 88.

29. Mahmud Yunus, Sejarah Pendidikan Islam, Cet. I; Jakarta: Hidakarya Agung, 1990, h. 174, Lihat juga: Abuddin Nata, op. cit., h. 91.

30. Ibid., h. 96.

31. Ibid., h. 92.

32. Ibid., h. 193.

33. Mahmud Yunus, op. cit., h. 176.

34. Ibid., h. 190.

35. Tim Penulis IAIN Syarif Hidayatullah, loc. cit.

36. Ibid., h. 190.

37. Abuddin Nata, op. cit., h. 107

38. Ibid., h. 192.

39. Pembaru Mesir yang berusaha memodernisasi institusi-institusi Islam yang membuat orang muslim memahami cita-cita Barat baru dan mempersatukan negaranya lagi. Lihat: Karen Armstrong, Islam a Short History, di terj. Iro Puspito Rini dengan judul Sepintas Sejarah Islam, Cet. III; Yogyakarta: Ikon Teralitera, 2003, h. 221.

40. Husayn Ahmad Amin, Al-Mi'ah al-A'zham fi Tarikh al-Islam, terj. Bahruddin Fannani, Seratus Tokoh dalam Sejarah Islam, Cet. III; Bandung: PT. Remaja Rosdakarya, 1999, h. 301.

41. Tim Penulis IAIN Syarif Hidayatullah, op. cit., h. 11.

42. Abuddin Nata, loc. cit.

43. Karen Armstrong, op. cit., h. 180.

44. Husayn Ahmad Amin, op. cit., h. 302.

45. Abuddin Nata, loc. cit. 
46. Zoel Qarnaen, Catatan, izoelas. Multiply.com/journal, diakses tanggal 6 Desember 2012.

47. Samsul Nizar, loc. cit.

\section{DAFTAR PUSTAKA}

Al-Abrasyi, Muhammad Atiyah. Al-Tarbiyah al-Islam. Terjemahan Bustami A. Gani dan Johar Bahri. Dasar-dasar Pokok Pendidikan Islam. Cet. VIII; Jakarta: Bulan Bintang, 1993.

Amin, Husayn Ahmad. Al-Mi'ah al-A'zham fi Tarikh al-Islam. Terjemahan Bahruddin Fannani. Seratus Tokoh dalam Sejarah Islam. Cet. III; Bandung: PT. Remaja Rosdakarya, 1999.

Amin, Samsul Munir, Sejarah Peradaban Islam, Cet. I; Jakarta: Amzah, 2009.

Armstrong, Karen. Islam a Short History. Terjemahan Iro Puspito Rini. Sepintas Sejarah Islam. Cet. III; Yogyakarta: Ikon Teralitera, 2003.

Asrohah, Hanun. Sejarah Pendidikan Islam. Cet. I; Jakarta: Logos, 1999.

Famhar. "Universitas Kelas Dunia." multiply.com/journal/item/189, diakses tanggal 6 Desember 2012.

Hitti, Philip K. History of The Arabs, Terjemahan R. Cecep Lukman Yasin dan Dedi Slamet Riyadi dgn judul: Sejarah Arab. Cet. I; Jakarta: Pt. Serambi Ilmu Semesta, 2008.

Nata, Abuddin. Sejarah Pendidikan Islam pada Periode klasik dan Pertengahan. Cet. I; Jakarta: PT. Raja Grafindo Persada, 2004.

Nizar, Samsul. Sejarah Pendidikan Islam Menelusuri Jejak Sejarah Pendidikan Era Rasulullah sampai Indonesia. Cet. III; Jakarta: Kencana, 2009.

Siba'i, Mustafa Husni. Min Rawaa'i Hadaraatina. Terjemahan Abdullah Zakiy al-Kaaf dengan judul: Khazanah Peradaban Islam. Cet. I; Bandung: Pustaka Setia, 2002.

Sunanto, Musyrifah. Sejarah Islam Klasik Perkembangan Ilmu Pengetahuan Islam. Cet. III; Jakarta: Kencana, 2007.

Thohir, Adjid. Perkembangan Peradaban di Kawasan Dunia Islam Melacak Akar-akar Sejarah, Sosial, Politik, dan Budaya Umat Islam. Cet. I; Jakarta: PT. Raja Grafindo Persada, 2009.

Tim Penulis IAIN Syarif Hidayatullah. Ensiklopedi Islam Indonesia. Cet. 2; Jakarta: Djambatan, 2002.

www.sunanampel.ac.id/index.php?limitstart=118danlang=in, diakses tanggal 3 Desember 2012.

Yunus, Mahmud. Sejarah Pendidikan Islam. Cet. I; Jakarta: Hidakarya Agung, 1990.

Zoel Qarnaen. “Catatan,” izoelas.multiply.com/journal, diakses tanggal 6 Desember 2010. 